\title{
Advanced mechanical circulatory support for post-cardiotomy cardiogenic shock: a 20-year outcome analysis in a non- transplant unit
}

\author{
Maziar Khorsandi ${ }^{*}$, Kasra Shaikhrezai ${ }^{2}$, Sai Prasad ${ }^{1}$, Renzo Pessotto ${ }^{1}$, William Walker ${ }^{1}$, Geoffrey Berg $^{2}$
} and Vipin Zamvar ${ }^{1}$

\begin{abstract}
Background: Post-cardiotomy cardiogenic shock (PCCS) has an incidence of 2-6\% after routine adult cardiac surgery. $0.5-1.5 \%$ are refractory to inotropic and intra-aortic balloon pump (IABP) support. Advanced mechanical circulatory support (AMCS) can be used to salvage carefully selected number of such patients. High costs and major complication rates have lead to centralization and limited funding for such devices in the UK. We have looked the outcomes of such devices in a non-transplant, intermediate-size adult cardiothoracic surgery unit.

Methods: Inclusion criteria included any adult patient who had received salvage veno-arterial extra-corporeal membrane oxygenation (V-A ECMO) or a ventricular assist device (VAD) for PCCS refractory to IABP and inotropic support following cardiac surgery from April 1995-April 2015.

Results: Sixteen patients met the inclusion criteria. Age range was 34-83 years (median 71). There was a male predominance of 12 (75\%). Overall, 15 (94\%) had received ECMO of which, 10 (67\%) had received central ECMO and 5 (33\%) had received peripheral ECMO. One patient $(6 \%)$ had a VAD. The most common complication was haemorrhage. Stroke, femoral artery pseudo-aneurysm, sepsis and renal failure also occurred. Thirty-day survival was $37.5 \%$. Survival rate to hospital discharge was $31.2 \%$. All survivors had NYHA class I-II at 24 months follow-up.

Conclusions: Our survival rate is similar to that reported in several previous studies. However, the use of AMCS for refractory PCCS is associated with serious complications. The survivors in our cohort appear to maintain an acceptable quality of life.
\end{abstract}

Keywords: Extracorporeal circulation, Heart-assist devices, Post-cardiotomy, Shock

\section{Background}

Post-cardiotomy cardiogenic shock (PCCS) occurs in $2-6 \%$ of patients undergoing surgical revascularization or valvular surgery [1-4]. Approximately $0.5-1.5 \%$ of patients are refractory to maximal inotropic and intraaortic balloon pump (IABP) support [5]. Post-cardiotomy cardiogenic shock occurs in perioperative cardiac surgery in patients with normal preoperative myocardial function as well as those with pre-existing impaired function [6].

\footnotetext{
* Correspondence: maziarkhorsandi@doctors.org.uk

'Department of Cardio-Thoracic Surgery, Royal Infirmary of Edinburgh, Edinburgh, UK

Full list of author information is available at the end of the article
}

Refractory PCCS leads rapidly to multi-organ dysfunction and is nearly always fatal $[4,7-9]$ without the use of advanced mechanical circulatory support (AMCS). AMCS devices such as extracorporeal membrane oxygenation (ECMO) and ventricular assist devices (VAD) have been used to salvage patients who develop refractory PCCS. Survival to hospital discharge is variable $[1-3,5,10-12]$ though long term survival and reasonable functional outcome can be achieved [11, 13-15]. However, these devices are associated with serious complications $[1,2,11,16-18]$ and are costly $[9,19,20]$. The UK National Health Service's (NHS) proposal to centralise AMCS funding to a few, larger cardiothoracic units has 
been controversial [15]. Some argue that such a move would remove this potentially, life-saving resource from those cardiothoracic surgery departments excluded from AMCS funding [15]. This prompted us to assess the outcome of the use of AMCS in a nontransplant, intermediate-sized unit (annual workload approximately 900 to 1000 major cardiac surgical operations) in Edinburgh, UK.

\section{Methods}

We retrospectively assessed our experience with AMCS in refractory PCCS over a 20-year period. These data were collected prospectively by the Royal Infirmary of Edinburgh cardiac surgery database. Our inclusion criteria included any adult patient from April 1995 to April 2015 who had received salvage V-A ECMO or VAD for PCCS refractory to IABP and maximal inotropic support following adult cardiac surgery. We gained information regarding the patients' follow-up status from accessing the cardiology follow-up clinic letters on the TrakCare ${ }^{R}$ system, which captures inpatient and out-patient clinical data.

The AMCS devices utilised by our unit in duration of the study included: The Levitronix ${ }^{\mathrm{R}}$ CentriMag II for ECMO and Medtronic Bio-Medicus ${ }^{\mathrm{R}} 560$ for VAD support.

\section{Results}

There were 18 patients who met the inclusion criteria. We excluded two patients who had had AMCS for refractory PCCS. One patient was in the paediatric age group and had been operated on prior to relocation of paediatric cardiac surgery services to the Royal Hospital for Sick Children, Glasgow in year 2000. Another patient was excluded due to the lack of recorded clarity in the database on the type of AMCS support used, any potential complications and the short and the long-term outcome of this individual. In the remaining 16 patients the age range was 34-83 years (Median 71 years).

Among the remaining 16 (89\%) patients (Table. 1), there was a large male predominance of 12 (75\%). Five patients $(31.25 \%)$ had undergone re-operative cardiac surgery. One patient (6.25\%) had undergone AMCS following the repair of an ascending aortic transection after a road traffic accident. Overall, 15 patients $(94 \%)$ had received a single run of $\mathrm{V}$-A ECMO of which number, $10(67 \%)$ had received central ECMO and $5(33 \%)$ had received peripheral ECMO. One patient (6\%) had VAD. The mean duration of AMCS was approximately 5.4 days (Range $<1$ day -33 days). The most common procedurerelated complication was major haemorrhage. The incidence of major cerebrovascular accident, peripheral limb ischaemia, femoral artery pseudo-aneurysm, septic shock and renal failure requiring renal replacement therapy was $18.75 \%, 12.5 \%, 6.25 \%, 12.5 \%$ and $18.75 \%$ respectively
(Fig. 1). Logistic EuroSCORE ranged from 2.08 to 73.26 (mean 20.21, SD = 17).

Most common cause of death (COD) was refractory biventricular failure (37.5\%, Fig. 2), in which group of patients, AMCS was withdrawn. One patient died due to combination of biventricular failure and haemorrhagic shock whilst on VA ECMO. Thirty-day survival was $37.5 \%$ (Fig. 3). Our survival rate to hospital discharge was $31.2 \%$. Upon reviewing the consultant cardiologist follow-up clinic letters on the TrakCare $^{\mathrm{R}}$ database, all survivors who were discharged home were alive at 24 months and had NYHA class I-II functional status on follow-up.

Advanced age, the emergent nature of surgery, preexisting, preoperative severe left ventricular impairment were identified as possible factors leading to an adverse outcome. These findings however are limited due to the small number of subjects and the retrospective nature of the study.

\section{Discussion \& review of the literature}

AMCS have been in evolution for almost 50 years. AMCS devices developed in parallel with the cardiopulmonary bypass (CPB) machine by John Gibbon in 1953 $[21,22]$. Soon after its inception, the CPB machine was being used to salvage patients following "failed" cardiac surgery. In 1966, Michael DeBakey used the first LVAD to support a patient who was in refractory PCCS [21]. After the first heart transplantation by Christiaan Barnard in 1967 and widespread acceptance of transplantation, AMCS devices have been regularly used to sustain those patients in refractory PCCS to allow time for decision for further management with implantable devices or heart transplantation [21].

There are two forms of ECMO; veno-venous (VV) which is usually utilized to support isolated respiratory failure and veno-arterial (VA) ECMO used to support cardiac, respiratory or mixed cardiorespiratory failure. Both types of ECMO can be applied centrally and peripherally $[23,24]$. There are two types of VADs. Shortterm, percutaneous VADs, which can be inserted in the catheter laboratory, serve as a temporizing measure to stabilize patients in acute cardiogenic shock. More longterm, surgically-implanted VADs are designed to increase patient's life span and/or bridge patients to transplantation [15]. VADs can be used to support the failing right ventricle, left ventricle or both. According to the UK VAD registry, scarcity of donor hearts has stimulated consideration of implantable AMCS devices for more prolonged circulatory support [20]. Recent studies have demonstrated that modern continuous flow AMCS devices such as CentriMag ${ }^{\mathrm{R}}$ pumps with magnetically levitated rotors and more effective modern oxygenators, can be more easily implanted, leading to much better 
Table 1 Illustrates patient characteristics, the type of mechanical circulatory support and outcomes over the 11-year study period

\begin{tabular}{|c|c|c|c|c|c|c|c|}
\hline & $\begin{array}{l}\text { Age \& } \\
\text { gender }\end{array}$ & $\begin{array}{l}\text { Co-morbidities \& } \\
\text { logistic euroSCORE }\end{array}$ & $\begin{array}{l}\text { Date of } \\
\text { surgery }\end{array}$ & Original operation & $\begin{array}{l}\text { Duration and mode } \\
\text { of AMCS }\end{array}$ & AMCS complication/s & Outcome \\
\hline \multirow[t]{8}{*}{ Patient 1} & \multirow{8}{*}{$\begin{array}{l}76 \text { year } \\
\text { old male }\end{array}$} & $\mathrm{Ml}$ & \multirow[t]{8}{*}{2012} & \multirow{8}{*}{$\begin{array}{l}\text { Re-do sternotomy } \\
\text { and AVR }\end{array}$} & \multirow{8}{*}{$\begin{array}{l}\text { Salvage peripheral } \\
\text { VA ECMO due to } \\
\text { postoperative } \\
\text { pulmonary } \\
\text { haemorrhage }\end{array}$} & \multirow{2}{*}{$\begin{array}{l}\text { Femoral artery } \\
\text { cannulation site } \\
\text { pseudoaneurysm }\end{array}$} & \multirow[t]{2}{*}{ Alive } \\
\hline & & CABG & & & & & \\
\hline & & Moderate LVSD & & & & \multirow{6}{*}{$\begin{array}{l}\text { Major haemorrhage } \\
\text { from cannulation site }\end{array}$} & \multirow{6}{*}{$\begin{array}{l}\text { NYHA I (No } \\
\text { breathlessness of } \\
\text { exertion, back } \\
\text { to work) }\end{array}$} \\
\hline & & Hypertension & & & & & \\
\hline & & Hypercholestrolaemia & & & & & \\
\hline & & ICD for VF & & & & & \\
\hline & & CVA & & & & & \\
\hline & & EurosCORE $=27.48$ & & & & & \\
\hline \multirow[t]{6}{*}{ Patient 2} & \multirow{6}{*}{$\begin{array}{l}40 \text { year } \\
\text { old male }\end{array}$} & MV repair & \multirow[t]{6}{*}{2014} & \multirow{6}{*}{$\begin{array}{l}\text { Re-do, Re-do } \\
\text { sternotomy for type } \\
\text { A aortic dissection: } \\
\text { Bentall procedure. }\end{array}$} & \multirow{6}{*}{$\begin{array}{l}\text { Salvage RVAD due to } \\
\text { VF arrest and } \\
\text { asystolic LV after CPB }\end{array}$} & \multirow{6}{*}{$\begin{array}{l}\text { Major haemorrhage } \\
\text { and re-exploration in } \\
\text { the operating theatre }\end{array}$} & Alive \\
\hline & & MVR & & & & & NYHA II \\
\hline & & Moderate LVSD & & & & & $\begin{array}{l}\text { (Breatioss on } \\
\text { exertion) }\end{array}$ \\
\hline & & Marfan's syndrome & & & & & \\
\hline & & AF & & & & & \\
\hline & & LogEuroSCORE = 29.18 & & & & & \\
\hline \multirow[t]{4}{*}{ Patient 3} & \multirow{4}{*}{$\begin{array}{l}82 \text { year } \\
\text { old male }\end{array}$} & Severe LVSD & \multirow[t]{4}{*}{2006} & \multirow[t]{4}{*}{ MV Repair and CABG } & 3 Days & \multirow{4}{*}{$\begin{array}{l}\text { Could not be } \\
\text { weaned from ECMO } \\
\text { with severe biVent } \\
\text { failure }\end{array}$} & Died in CTICU \\
\hline & & $\mathrm{Ml}$ & & & \multirow{3}{*}{$\begin{array}{l}\text { VA ECMO as unable } \\
\text { to wean from CPB }\end{array}$} & & \multirow{3}{*}{$\begin{array}{l}\text { COD: BiVent } \\
\text { failure }\end{array}$} \\
\hline & & Severe TVD & & & & & \\
\hline & & LogEuroSCORE $=17.45$ & & & & & \\
\hline \multirow[t]{3}{*}{ Patient 4} & \multirow{3}{*}{$\begin{array}{l}72 \text { year } \\
\text { old } \\
\text { Female }\end{array}$} & Good LV function & 2011 & AVR & 9 Days & Septic shock & Died in CTICU \\
\hline & & Moderate MR & & & VA ECMO as unable & Peripheral ischaemia & COD: Septic shock \\
\hline & & EuroSCORE $=12.11$ & & & to come off CPB & & \\
\hline Patient 5 & $\begin{array}{l}71 \text { year } \\
\text { old male }\end{array}$ & $\begin{array}{l}\text { Urgent/Emergency } \\
\text { Surgery }\end{array}$ & 2011 & CABGX3 and AVR & 2 Days & $\begin{array}{l}\text { ECMO cannulation } \\
\text { site bleeding and } \\
\text { haematoma explored }\end{array}$ & Died in CTICU \\
\hline & & MI (<90 days) & & & Peripheral VA ECMO & Renal failure ${ }^{a}$ & COD: Shock \\
\hline & & Severe LVSD & & & $\begin{array}{l}\text { as unable to come } \\
\text { off CPB }\end{array}$ & & (unknown cause) \\
\hline & & Severe TVD & & & & & \\
\hline & & Anaemia & & & & & \\
\hline & & LogEuroSCORE $=26.35$ & & & & & \\
\hline Patient 6 & 83 year & Urgent/Emergency & 2012 & MVR and $C A B G \times 1$ & $<1$ Day & None & Died in CTICU \\
\hline & $\begin{array}{l}\text { Old } \\
\text { female }\end{array}$ & surgery & & & Peripheral VA ECMO & & COD: BiVent \\
\hline & & MI (<90 days) & & & as unable to come & & failure \\
\hline & & Severe LVSD & & & awaited family to see & & \\
\hline & & Acute severe MR & & & patient last time & & \\
\hline & & Cardiogenic shock & & & & & \\
\hline & & LogEuroSCORE = 73.26 & & & & & \\
\hline Patient 7 & 70 year & $\mathrm{Ml}$ & 2013 & Re-do sternotomy & 33 Days & Major CVA & Died in HDU \\
\hline & & CABG & & & VA ECMO. & & COD: severe \\
\hline & & CVA & & & $\begin{array}{l}\text { Successfully weaned } \\
\text { from ECMO }\end{array}$ & & Respiratory failure \\
\hline & & Hypertension & & & & & \\
\hline & & Hypercholestrolaemia & & & & & \\
\hline & & Good LV & & & & & \\
\hline & & LogEuroSCORE $=14.31$ & & & & & \\
\hline
\end{tabular}


Table 1 Illustrates patient characteristics, the type of mechanical circulatory support and outcomes over the 11-year study period (Continued)

\begin{tabular}{|c|c|c|c|c|c|c|c|}
\hline \multirow[t]{4}{*}{ Patient 8} & \multirow[t]{4}{*}{$\begin{array}{l}72 \text { year } \\
\text { old male }\end{array}$} & $\begin{array}{l}\text { Moderate LVSD } \\
\text { CABG }\end{array}$ & \multirow[t]{4}{*}{2013} & \multirow[t]{4}{*}{$\begin{array}{l}\text { Re-do sternotomy } \\
\text { and AVR }\end{array}$} & $<1$ Day & $\begin{array}{l}\text { ECMO cannulation } \\
\text { femoral artery } \\
\text { dissection }\end{array}$ & Died in CTICU \\
\hline & & Atrial flutter & & & \multirow{3}{*}{$\begin{array}{l}\text { VA ECMO after } \\
\text { iatrogenic aortic } \\
\text { dissection during } \\
\text { Femoral cannulation } \\
\text { for bypass }\end{array}$} & \multirow[t]{3}{*}{ Major haemorrhage } & \multirow[t]{3}{*}{ COD: Major CVA } \\
\hline & & Hypertension & & & & & \\
\hline & & LogEuroSCORE $=13.09$ & & & & & \\
\hline \multirow[t]{2}{*}{ Patient 9} & \multirow{2}{*}{$\begin{array}{l}51 \text { year } \\
\text { old male }\end{array}$} & Moderate LVSD & \multirow[t]{2}{*}{2013} & \multirow{2}{*}{$\begin{array}{l}\text { Re-suspension of } \\
\text { Aortic } \\
\text { valve and repair of } \\
\text { type } A \text { aortic } \\
\text { dissection }\end{array}$} & 1 Day & \multirow{2}{*}{$\begin{array}{l}\text { Major cannulation } \\
\text { site haemorrhage }\end{array}$} & Died in CTICU \\
\hline & & LogEuroSCORE $=13.13$ & & & Peripheral VA ECMO & & $\begin{array}{l}\text { COD: } \\
\text { Haemorrahgic } \\
\text { shock and BiVent } \\
\text { failure }\end{array}$ \\
\hline \multirow[t]{2}{*}{ Patient 10} & \multirow{2}{*}{$\begin{array}{l}34 \text { year } \\
\text { old } \\
\text { female }\end{array}$} & Good LV & \multirow[t]{2}{*}{2014} & \multirow{2}{*}{$\begin{array}{l}\text { IVC Leiomyosarcoma } \\
\text { resection }\end{array}$} & 3 Days & \multirow[t]{2}{*}{ None } & Died in CTICU \\
\hline & & LogEuroSCORE $=2.08$ & & & VA ECMO & & $\begin{array}{l}\text { COD: BiVent } \\
\text { failure from acute } \\
\text { MI }\end{array}$ \\
\hline \multirow[t]{3}{*}{ Patient 11} & \multirow{3}{*}{$\begin{array}{l}65 \text { year } \\
\text { old male }\end{array}$} & Urgent surgery & \multirow[t]{3}{*}{2013} & \multirow[t]{3}{*}{ CABG } & 2 Days & Renal failure ${ }^{a}$ & Died in CTICU \\
\hline & & $\begin{array}{l}\text { ACS (Unstable } \\
\text { angina) }\end{array}$ & & & Salvage VA ECMO & Hepatic failure & COD: MODS \\
\hline & & LogEuroSCORE $=4.55$ & & & & Pulmonary oedema & \\
\hline \multirow[t]{3}{*}{ Patient 12} & \multirow[t]{3}{*}{$\begin{array}{l}71 \text { year } \\
\text { old male }\end{array}$} & $\begin{array}{l}\text { Peripheral } \\
\text { vasculopath }\end{array}$ & \multirow[t]{3}{*}{2015} & \multirow[t]{3}{*}{ CABG } & 3 Days & \multirow{2}{*}{$\begin{array}{l}\text { Major haemorrhage: } \\
\text { Re-opening for } \\
\text { bleeding } \times 4\end{array}$} & \multirow[t]{2}{*}{ Died in CTICU } \\
\hline & & LogEuroSCORE $=3.67$ & & & & & \\
\hline & & & & & $\begin{array}{l}\text { VA ECMO as unable } \\
\text { to wean from CPB }\end{array}$ & $\begin{array}{l}\text { Peripheral leg } \\
\text { ischaemia }\end{array}$ & $\begin{array}{l}\text { COD: biventricular } \\
\text { failure and septic } \\
\text { shock }\end{array}$ \\
\hline \multirow[t]{4}{*}{ Patient 13} & 49 year & Emergency Surgery & 1997 & CABG & VA ECMO & Note recorded & Alive (Died 2004) \\
\hline & & PVD & & & & & \\
\hline & & Intra-operative MI & & & & & \\
\hline & & LogEuroSCORE $=5.69$ & & & & & \\
\hline Patient 14 & 69 year & Active IE & 2004 & MVR and CABG for & VA ECMO & CVA and seizures & Alive NYHA ॥ \\
\hline & Old male & Emergency surgery & & & & & \\
\hline & & Moderate LVSD & & & & & \\
\hline & & LogEuroSCORE $=21.73$ & & & & & \\
\hline Patient 15 & 41 year & Emergency surgery & 2005 & Aortic transection & VA ECMO & Not recorded & Alive NYHA I \\
\hline & female & Good LV & & $\begin{array}{l}\text { and diaphragmatic } \\
\text { rupture }\end{array}$ & & & \\
\hline & & LogEuroSCORE $=25.50$ & & & & & \\
\hline Patient 16 & 59 year & MI (<90 days) & 2006 & Type A aortic & 2 Days & Not recorded & Died COD: Bivent \\
\hline & old male & Severe LVSD & & dissection & Peripheral VA ECMO & & tallure \\
\hline & & Emergency surgery & & & $\begin{array}{l}\text { as unable to come } \\
\text { off bypass }\end{array}$ & & \\
\hline & & LogEuroSCORE $=33.90$ & & & & & \\
\hline
\end{tabular}

Abbreviations: $A C S$ acute coronary syndrome, $A F$ atrial fibrillation, $A M C S$ advanced mechanical circulatory support, $A V R$ aortic valve replacement, $C A B G$ coronary artery bypass grafting surgery, $C P B$ cardiopulmonary bypass, $C O D$ cause of death, BiVent failure biventricular failure, $M V R$ mitral valve replacement, IE infective endocarditis, CVA cerebrovascular accident, IVC, inferior vena-cava, NYHA New York Heart Association, CTICU cardiothoracic intensive care unit, HDU high dependency unit, implantable cardioverter defibrillator, $M I$ myocardial infarction, $L V S D$ left ventricular systolic dysfunction, $T V D$ triple vessel coronary artery disease, $L V$ left ventricular, $M R$ mitral regurgitation, $P V D$ peripheral vascular disease, MODS multi-organ dysfunction syndrome, $V F$ ventricular fibrillation, $V A D$ ventricular assist device, $V A$ veno-arterial; ${ }^{a}$ All patients with renal failure required renal replacement therapy

survival in patients with post-cardiotomy cardiogenic shock in the recent years [25-27].

In our literature search we identified 15 major articles. In the largest cohort, Hernandez et al. [3] collated data from 5,735 patients who underwent salvage VAD support for refractory PCCS. They reported $54.1 \%$ survival rate to hospital discharge. They concluded that VAD is a valuable, life-saving therapeutic manoeuvre. Rastan et al. 


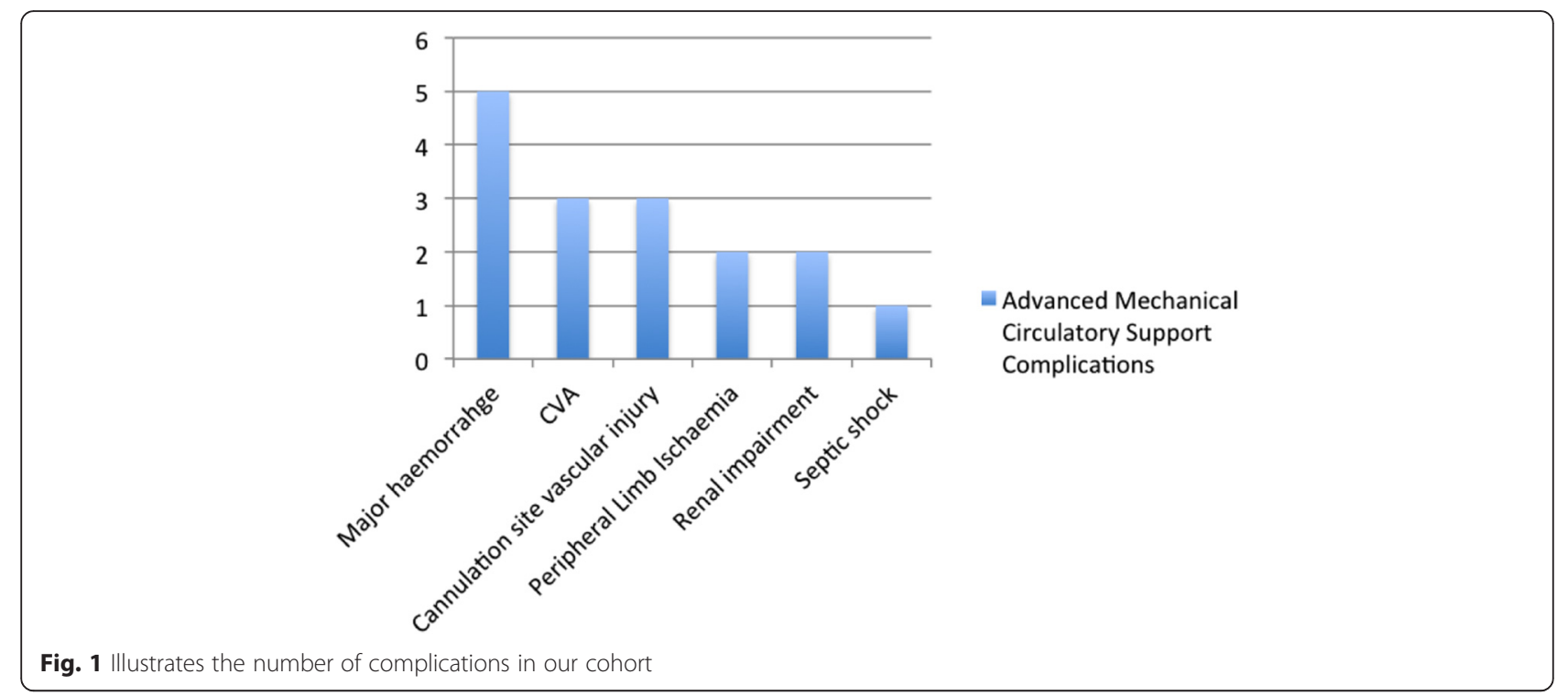

[5] performed ECMO support in 516 patients with refractory PCCS. A total of $24.8 \%$ of patients survived to discharge to the community. However, after 5 years $13.7 \%$ were alive and $17.4 \%$ of patients suffered severe morbidity [5]. In another large cohort of 219 patients Doll et al. [28] reported $24.8 \%$ survival to discharge and $16.9 \%$ 5-year survival for their cohort of refractory PCCS patients who had received salvage ECMO support. Hsu et al [12] reported a cohort of 51 patients who had undergone cardiac surgery and suffered refractory PCCS requiring ECMO circulatory support. The 30-day, 3month and 1-year mortality rates were 49, 65 and $71 \%$ respectively. Mehta et al. [13] reported a large cohort of 1,279 patients who had undergone VAD for circulatory support for refractory PCCS. They claimed that 584
(45.7\%) patients were successfully weaned from VAD and $323(25.3 \%)$ patients survived to discharge from the hospital. In a small cohort of 12 patients with refractory PCCS, DeRose et al. [2] reported that 9 patients (75\%) survived to discharge from the hospital with LVAD implantation, $8(67 \%)$ survived to transplantation and 1 (8 \%) successfully underwent explanation of LVAD not requiring transplantation. However, they reported $42 \%$ rate of LVAD related infective complications.

With respect to longer term outcomes; a study by Ko et al. [11] reported a cohort of 76 patients undergoing ECMO support for refractory PCCS. They reported that, although 46 patients $(60.5 \%)$ were successfully weaned from ECMO, 20 (26.3\%) survived to discharge. However all survivors were reported to be of

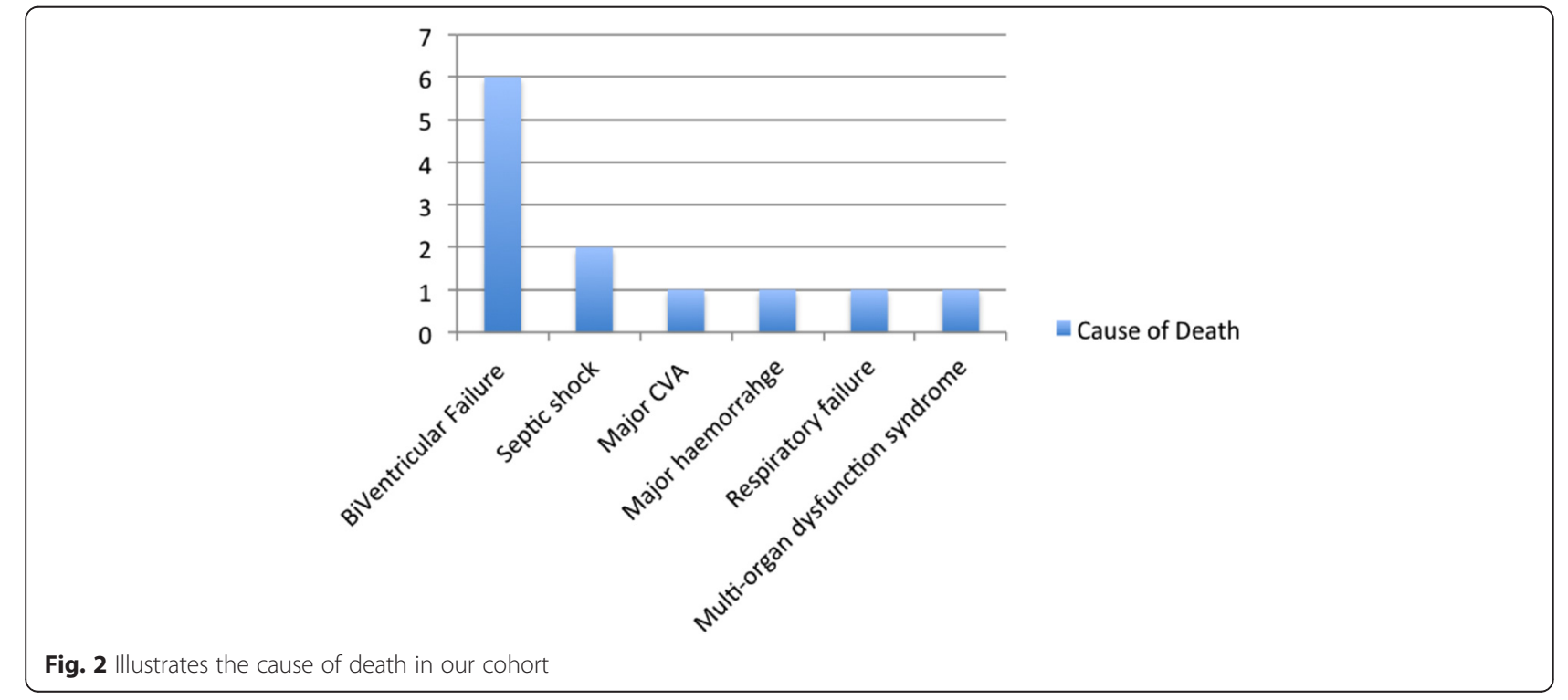




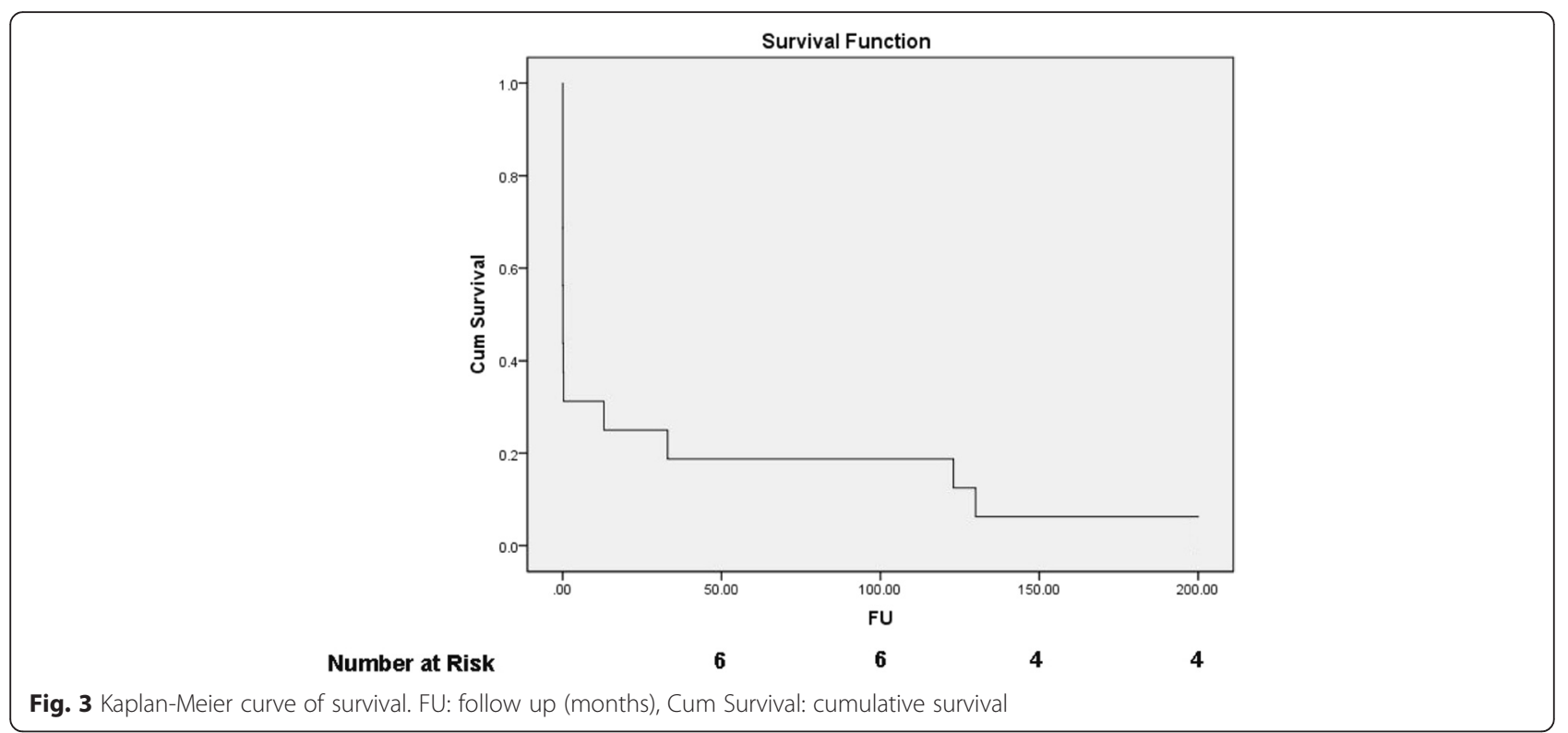

New York Heart Association (NYHA) I and II functional status on $32+/-22$ month follow-up. This quality of life finding is in keeping with the findings in our cohort. Pennington et al. [17] reported refractory PCCS support with VAD with $37 \%$ survival to hospital discharge. They reported that all survivors were "leading active lives". In $72.7 \%$ of survivors ejection fraction had normalized on follow-up echocardiogram. AMCS devices also have disadvantages. They are currently not funded within the cardiac surgery tariff and are quite costly $[9,19,20]$. According to a study conducted at the University Hospital of South Manchester [9] (an NHS institution), the cost of capital equipment, device maintenance and single-use elements (e.g. tubing) of the CentriMag ${ }^{\mathrm{R}}$ device is $£ 3542$. The total per patient cost of VAD and ECMO were reported as $£ 15669$ and $£ 8616$ respectively. However the costs associated with the device and the ICU stay may vary substantially depending on the duration of AMCS. The cost of implantable VAD per patient receiving a device is $£ 173,841$ or US $\$ 316,078$. The most costly aspect is implantation of the device $(£ 63,830$, US\$116,056) and the initial hospital stay in the ITU and ward totals as much as $£ 14,500$ or US\$26,364 [29]. A clinical trial indicated the cost of quality adjusted life year for ECMO in the UK to be $£ 19,252$ [30]. Also there are reports [1, 2, 11, 16-18] of serious device-related complications including: bleeding, thrombus formation and embolization, cerebrovascular accidents, device infection, limb ischaemia and multi-organ dysfunction syndrome/failure. However, there is evidence that on-the-table, early implantation of AMCS devices, prior to leaving the operating theatre from the initial operation, substantially improves survival as compared to late implantation out-with the operating theatre [6, 26]. Given the reported survival rates and the extent of resources involved, we recommend that each case should be assessed in its own individual merit. Involvement of a cardiac surgeon, other than the surgeon involved in the initial operation, the clinical director of the department of cardiac surgery, as well as involving the perfusionist and the on-call anaesthetist in the decision making process is imperative in gaining optimal outcomes for patients undergoing AMCS for refractory PCCS while optimising the costbenefit equation.

\section{Conclusion}

AMCS devices can be used to salvage some patients with refractory PCCS who would otherwise have not survived. However, ACMS are associated with high rates of severe, systemic and device-related complications as well being costly. We recommend team approach to decision-making and early application of AMCS to the few carefully selected patients with refractory PCCS in order to optimise the cost-benefit equation. Our results reflect findings from previous studies. Our study showed survivors enjoyed a reasonable quality of life.

\section{Competing interest}

The authors declare that they have no competing interests.

\section{Authors' contribution}

MK: Primary investigator, presented at the WSCTS 2015, manuscript preparation. KS: Manuscript drafting and preparation. SP: Manuscript editing. RP: Manuscript editing. WW: Manuscript editing. GB: Manuscript editing. VZ: Project supervisor and senior author. All authors read and approved the final manuscript.

\section{Acknowledgements}

International Meeting Presentation: Oral presentation \& shortlisted for a prize at the World Society of Cardiothoracic Surgery (WSCTS), 2015. 


\section{Funding}

No funding was claimed for this study.

\section{Author details}

'Department of Cardio-Thoracic Surgery, Royal Infirmary of Edinburgh, Edinburgh, UK. ${ }^{2}$ Department of Cardio-Thoracic Surgery, Golden Jubilee National Hospital, Glasgow, UK.

Received: 18 November 2015 Accepted: 15 February 2016 Published online: 18 February 2016

\section{References}

1. Muehrcke DD, McCarthy PM, Stewart RW, Foster RC, Ogella DA, Borsh JA, et al. Extracorporeal membrane oxygenation for postcardiotomy cardiogenic shock. Ann Thorac Surg. 1996;61:684-91.

2. DeRose JJ, Umana JP, Argenziano M, Catanese KA, Levin HR, Sun BC, et al. Improved results for postcardiotomy cardiogenic shock with the use of implantable left ventricular assist devices. Ann Thorac Surg. 1997;64:1757-63.

3. Hernandez AF, Grab JD, Gammie JS, O'Brien SM, Hammill BG, Rogers JG, et al. A decade of short-term outcomes in post-cardiac surgery ventricular assist device implantation. Circulation. 2007;116:606-12

4. Mohite PN, Sabashnikov A, Patil NP, Sáez DG, Zych B, Popov AF, et al. Shortterm ventricular assist device in post-cardiotomy cardiogenic shock: factors influencing survival. J Artif Organs. 2014;17(3):228-35.

5. Rastan AJ, Dege A, Mohr M, Doll N, Falk V, Walther T, et al. Early and late outcomes of 517 consecutive adult patients treated with extracorporeal membrane oxygenation for refractory postcardiotomy cardiogenic shock. J Thorac Cardiovasc Surg. 2010;139:302-11.

6. Delgado DH, Rao V, Ross HJ, Verma S, Smedira NG. Mechanical circulatory assistance: state of art. Circulation. 2002;106:2046-50.

7. Beurtheret $S$, Mordant P, Paoletti X, Marijon E, Celermajer DS, Le'ger P, et al. Emergency circulatory support in refractory cardiogenic shock patients in remote institutions: a pilot study (the cardiac-RESCUE program). Eur Heart J. 2012;34(2):112-20

8. Goldstein DJ MCO. Mechanical support for postcardiotomy cardiogenic shock. Semin Thorac Cardiovasc Surg. 2000;12(3):220-8

9. Borisenko O, Wylie G, Payne J, Bjessmo S, Smith J, Firmin R, et al. The cost impact of short-term ventricular assist devices and extracorporeal life support systems therapies on the National Health Service in the UK. Interact Cardiovasc Thorac Surg. 2014;19:41-8

10. De Robertis F, Birks EJ, Rogers P, Dreyfus G, Pepper JR, Khaghani A. Clinical performance with the levitronix centrimag short-term ventricular assist device. J Heart Lung Transplant. 2006;25:181-6.

11. Ko WJ, Lin CY, Chen RJ, Wang SS, Lin FY, Chen YS, et al. Extracorporeal membrane oxygenation support for adult postcardiotomy cardiogenic shock. Ann Thorac Surg. 2002;73:538-45

12. Hsu PS, Chen JL, Hong GJ, Tsai YT, Lin CY, Lee CY, et al. Extracorporeal membrane oxygenation for refractory cardiogenic shock after cardiac surgery: predictors of early mortality and outcome from 51 adult patients. Eur J Cardiothorac Surg. 2010;37:328-33.

13. Mehta SM, Aufiero TX, Pae WE, Miller CA, Pierce WS. Results of mechanical ventricular assistance for the treatment of post cardiotomy cardiogenic shock. ASAIO J. 1996:42:211-8.

14. Pae WE, Pierce WS, Pennock $J \mathrm{~L}$, Campbell DB, JA W. Long-term results of ventricular assist pumping in postcardiotomy cardiogenic shock. J Thorac Cardiovasc Surg. 1987:93(3):434-41.

15. Westaby S, Taggart D. Inappropriate restrictions on life saving technology. Heart. 2012;98(15):1117-9.

16. Xiao XJ, Luo ZX, Ye CX, Fan RX, Yi DH, Ji SY, et al. The short-term pulsatile ventricular assist device for postcardiotomy cardiogenic shock: a clinical tria in China. Artif Organs. 2009;33(4):373-7.

17. Pennington DG, McBride LR, Swartz M, Kanter KR, Kaiser GC, Barner HB, et al. Use of the pierce-donachv ventricular assist device in patients with cardiogenic shock after cardiac operations. Ann Thorac Surg. 1989;47:130-5.

18. Zumbro GL, Kitchens WR, Shearer G, Harville G, Bailey L, Galloway RF, et al. Mechanical assistance for cardiogenic shock following cardiac surgery, myocardial infarction, and cardiac transplantation. Ann Thorac Surg. 1987; 44(1):11-3.

19. Miller LW, Guglin M, Rogers J. Cost of ventricular assist devices: can we afford the progress? Circulation. 2013;127:743-8.
20. Emin A, Rogers CA, Parameshwar J, MacGowan G, Taylor R, Yonan N, et al. Trends in long-termmechanical circulatory support for advanced heart failure in the UK. Eur J Heart Fail. 2013;15:1185-93.

21. Stewart GC, Giverts MM. Mechanical circulatory support for advanced heart failure: Patients and technology in evolution. Circulation. 2012;125:1304-15.

22. Fou AA. John H. Gibbon. The first 20 years of the heart-lung machine. Tex Heart Inst J. 1997:24(1):1-8.

23. Aubron C, Cheng AC, Pilcher D, Leong T, Magrin G, Cooper DJ, et al. Factors associated with outcomes of patients on extracorporeal membrane oxygenation support: a 5-year cohort study. Crit Care. 2013;17(2):1-12.

24. Interventional procedure overview of extracorporeal membrane oxygenation (ECMO) for acute heart failure in adults. National Institute for Health and Care Excellence (NICE); 2013. p. 1-40. https://www.nice.org.uk/ guidance/ipg482/resources/extracorporeal-membrane-oxygenation-ecmofor-acuteheart-failure-in-adults-1899869988516037.

25. Mikus E, Tripodi A, Calvi S, Giglio MD, Cavallucci A, Lamarra M. CentriMag venoarterial extracorporeal membrane oxygenation support as treatment for patients with refractory postcardiotomy cardiogenic shock. ASAIO J. 2013;59(1):18-23.

26. Akay MH, Gregoric ID, Radovancevic R, Cohn WE, Frazier OH. Timely use of centrimag heart assist device improves survival in postcardiotomy cardiogenic shock. J Card Surg. 2011;26(5):548-52.

27. Peura JL, Colvin-Adams M, Francis GS, Grady KL, Hoffman TM, Jessup M, et al. Recommendations for the use of mechanical circulatory support: device strategies and patient selection. Circulation. 2012;126:2648-67.

28. Doll NKB, Borger M, Bucerius J, Kramer K, Schmitt D, et al. Five year results of 219 consecutive patients treated with extracorporeal membrane oxygenation after refractory postoperative cardiogenic shock. Ann Thorac Surg. 2004;77:151-7.

29. Sharples LD, Dyer M, Cafferty F, Demiris N, Freeman C, Banner NR, et al. Cost-effectiveness of ventricular assist device use in the United Kingdom: results from the Evaluation of Ventricular Assist Device Programme in the UK (EVAD-UK). J Heart Lung Transplant. 2006:25(11):1336-43.

30. Stewart NI, Gunning K, Cuthbertson BH. Regionalisation of intensive care and extra-corporeal membrane oxygenation services in the UK: beliefs about the evidence, benefits and harm. J Intensive Care Society. 2012;13(3):244-50.

\section{Submit your next manuscript to BioMed Central and we will help you at every step:}

- We accept pre-submission inquiries

- Our selector tool helps you to find the most relevant journal

- We provide round the clock customer support

- Convenient online submission

- Thorough peer review

- Inclusion in PubMed and all major indexing services

- Maximum visibility for your research

Submit your manuscript at www.biomedcentral.com/submit 